\title{
Note
}

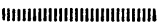

\section{Detection of Tumor-inducing Plasmid DNA Sequence in Agrobacterium tumefaciens by DNA-DNA Hybridization ${ }^{\dagger}$}

\author{
Kazuhiko Furukawa, Kohji Hasunuma, Shin-ichi Hatanaka* \\ and Toshio HaYashi* \\ Radioisotope Facilities, National Institute for Basic Biology, Okazaki National Research Institutes \\ 38, Nishigonaka, Myodaiji-cho, Okazaki-shi, Aichi Pref. 444, Japan \\ * Department of Biology, College of Arts and Sciences, University of Tokyo \\ 8-1, Komaba 3-chome, Meguro-ku, Tokyo 153, Japan \\ Received March 9, 1984
}

\begin{abstract}
Absence of plasmid DNA sequences in non-tumorigenic (crown gall tumor) strains of Agrobacterium tumefaciens was confirmed by DNA-DNA hybridization between purified tumor-inducing (Ti) plasmid DNAs isolated from the progenitor tumorigenic strains and ${ }^{3} \mathrm{H}-$ labeled whole cell DNAs from tumorigenic strains and their non-tumorigenic derivatives. The genes controlling tumorigenicity in plant and utilizability of nopaline as their sole nitrogen source were confirmed to locate on Ti-plasmids.
\end{abstract}

Key Words: tumor-inducing plasmid DNA, tritium-labeled whole cell DNA, DNA-DNA hybridization, non-tumorigenicity

\section{Introduction}

Virulent strains of Agrobacterium tumefaciens which induce crown gall tumors in dicotyledonous plants contain large plasmids (1.0 $1.5 \times 10^{8}$ daltons) designated as tumor-inducing (Ti)-plasmid ${ }^{1}$. The octopine-type Ti-plasmids confer upon their bacterial host the ability to utilize octopine as a sole nitrogen source and the nopaline-type Ti-plasmids the ability to utilize nopaline ${ }^{2}$. Both types of Ti-plasmids also confer on the bacterial host to induce tumors in plant and to induce the enzymes which synthesize tumor-specific octopine or nopaline in plants ${ }^{2}$. In the presence of octopine, the transfer of octopine-type Ti-plasmid was stimulated $^{3,4)}$ and transfer of Ti-plasmid and octopine degradation were coordinately regu-

† DNA-DNA ハイブリダイゼーションによる Agrobacterium tumefaciens 植物がん誘起プラスミド DNA の塩基配列の検知。古川和彦, 蓮沼仰嗣, 畑中信一*, 林俊郎*: 岡崎国立共同研究機構基礎 生物学研究所フイントープ実験施設, 444 岡崎市 明大寺町西郷中 $38, *$ 東京大学 教養学部 生物学教 室, 153 東京都目黒区駒場3-8-1. lated by a common repressor gene ${ }^{4)}$. Tumorigenic Agrobacterium strains and the nontumorigenic ones derived from the former, however, contained in some case large and small plasmids $^{5,6)}$ and the analyses to detect plasmid DNA were carried out either by sucrose density gradient centrifugation or $\mathrm{CsCl}$-dye buoyant density gradient centrifugation ${ }^{1), 7)}$. With these methods plasmid DNA integrated in the host bacterial chromosome can not be detected. To establish the experimental system for the study of these plasmid dependent phenomena and to make unambiguous confirmation of them, the presence or absence of plasmid DNA sequence in the non-tumorigenic strains derived from the tumorigenic ones was required to be determined. In the present study, non-existence of plasmid DNA sequence in the two nontumorigenic strains, $1 \mathrm{D} 1300$ and 1D1329, derived from tumorigenic strains, 1D1159 and 1D135, respectively, was demonstrated by DNADNA hybridization with immobilized plasmid DNAs on membrane filters. 


\section{Materials and Methods}

\subsection{Bacterial strains}

Nopaline type tumorigenic strains, 1D135 and 1D1159, and non-tumorigenic strains derived from them, 1D1329 and 1D1300, were supplied from Kado, University of California. An octopine type tumorigenic strain, B6 was a gift from Hildebrandt, University of Wisconsin, and also octopine type tumorigenic strain, IAM1525 was supplied from Institute of Applied Microbiology, The University of Tokyo.

\section{$2 \cdot 2$ Media}

LB medium contained $10 \mathrm{~g}$ of Bactopeptone, $5 \mathrm{~g}$ of yeast extract (Difco) and $10 \mathrm{~g}$ of $\mathrm{NaCl}$ per liter, with adjustment of $\mathrm{pH}$ to 7.0 with $1 \mathrm{~N} \mathrm{NaOH}$. LB-agar contained $15 \mathrm{~g}$ of agar per liter of LB medium. Nitrogen-free medium was prepared according to Van Larebeke, et al. ${ }^{8)}$ All reagents used were analytical grade, and deionized distilled water was used. Nopaline and iso-nopaline media contained $100 \mu \mathrm{g} / \mathrm{ml}$ of each, separately in $\mathrm{N}$-free medium. Nopaline and iso-nopaline were prepared by Hatanaka ${ }^{9}$. Their agar plates contained 1.5\% Agar Noble (Difco) purified by washing 3 times with 70 volumes of deionized distilled water.

\subsection{Isolation of plasmid DNA}

The plasmid DNA was isolated by the partially modified method of Currier and Nester ${ }^{10}$. Twenty $\mathrm{m} l$ of overnight culture (seed culture) was inoculated to $1 l$ of LB medium, followed by culture at $25^{\circ} \mathrm{C}$ with shaking. At a culture age of about $2 \times 10^{8} \mathrm{cells} / \mathrm{ml}$, the cells were harvested by centrifugation and washed twice with $40 \mathrm{ml}$ of a buffer, $0.05 M$ trisHCl-0.02 $M$ EDTA, pH 8.0. The washed cells were then suspended in $100 \mathrm{~m} l$ of the above buffer, and incubated in the presence of lysozyme $(500 \mu \mathrm{g} / \mathrm{ml})$ for $10 \mathrm{~min}$ at $37^{\circ} \mathrm{C}$ with further incubation in the additional presence of $100 \mu \mathrm{g} / \mathrm{ml}$ of protease (Sigma, Type V) and $1.0 \%$ of sodium dodecyl sulfate (SDS) for $10 \mathrm{~min}$ at $37^{\circ} \mathrm{C}$. The subsequent procedures for the isolation of plasmid were essentially the same as described by Currier and Nester ${ }^{10}$.

\subsection{Labeling and isolation of whole DNA}

One fiftieth volume of seed culture of the bacterium was inoculated to $10 \mathrm{ml}$ of LB medium, and after $1 \mathrm{~h}$ cultivation at $25^{\circ} \mathrm{C}$ with shaking, $\left[{ }^{3} \mathrm{H}\right]$ thymidine was added to a final concentration of $3.7 \mathrm{MBq} / \mathrm{m} l(100 \mu \mathrm{Ci} / \mathrm{m} l)$. The cultivation was carried out to a cell density of $5 \times 10^{8}$ cells $/ \mathrm{m} l$. The cells were harvested by centrifugation, and treated with the lysis reagent of Guerry, et al. ${ }^{11)}$ To the cell lysate was added $500 \mu \mathrm{g}$ of E. coli cellular DNA, and a volume of the lysate was made $5.0 \mathrm{ml}$ with $10 \mathrm{mM}$ tris-HCl-1 mM EDTA, pH 7.5 (TE buffer). After shearing DNA in the lysate by a vortex mixer, the lysate was treated with an equal volume of phenol saturated with TE buffer, and buffer layer (aqueous layer) was separated by centrifugation. Further $5 \mathrm{ml}$ of TE buffer was added to the phenol layer and mixed for DNA extraction. The buffer layers were combined and treated with 2 volumes of isopropanol. The DNA precipitate formed was collected by centrifugation and dissolved in TE buffer. Appropriate amount of $5 \mathrm{~N} \mathrm{NaOH}$ was added, giving DNA solution in $0.5 \mathrm{~N} \mathrm{NaOH}$. The DNA solution was heated in boiling water for $7 \mathrm{~min}$ and immediately chilled in ice water, followed by a successive dialysis against $1 l$ of $1 M$ NaCl-10 $\mathrm{mM}$ tris, $\mathrm{pH} 7.0$, and $50 \mathrm{mM}$ tris- $\mathrm{HCl}, \mathrm{pH} 7.0$, each for at least $5 \mathrm{~h}$ at $4^{\circ} \mathrm{C}$.

\subsection{DNA-DNA hybridization}

To $0.9 \mathrm{ml}$ of plasmid DNA solution containing $20 \mu \mathrm{g}$ of DNA, $0.1 \mathrm{~m} l$ of $5 \mathrm{~N} \mathrm{NaOH}$ was added and boiled for $7 \mathrm{~min}$. The plasmid solution was then mixed with $9 \mathrm{~m} l$ of $\times 6 \mathrm{SSC}$ (SSC is $0.15 M$ NaCl-0.015 $M$ sodium citrate, $\mathrm{pH}$ 7.0) and adjusted pH to 7.0 with $5 \mathrm{~N} \mathrm{HCl}$. The DNA solution was heated in boiling water for $5 \mathrm{~min}$, chilled with ice water and immediately fixed on a millipore filter, HAWP $(0.45 \mu \mathrm{m})$. The filter with DNA was dried under reduced pressure overnight and baked at $80^{\circ} \mathrm{C}$ for $2 \mathrm{~h}$. DNA-DNA hybridization was carried out by the method described by Denhardt ${ }^{12}$.

\subsection{Plant test}

Kalanchoë daigremontiana and sunflower were used as test plants. A. tumefaciens bac- 
terial pastes were inoculated by a sterilized needle on their wounded stems in a greenhouse.

\section{Results and Discussion}

\subsection{Detection of plasmid DNA sequence by DNA-DNA hybridization}

Though the non-tumorigenic strains, 1D1300 and 1D1329 were obtained as those cured of Ti-plasmid (nopaline-type) from tumorigenic strains, 1D1159 and 1D135, respectively, there remained the following two possibilities; (1) a part of or whole plasmid DNA is integrated in the host chromosome and (2) a small plasmid derived from the large plasmid exists which can not be detected by alkaline and neutral sucrose density gradient centrifugation. To check these possibilities, the presence of plasmid DNA sequence in the non-tumorigenic strains was examined by DNA-DNA hybridization. Strains 1D135, 1D1159, 1D1329 and 1D1300 were labeled with $\left[{ }^{3} \mathrm{H}\right]$ thymidine, and whole DNAs from these strains were hybridized with plasmid DNA purified from strains, 1D135 and 1D1159.

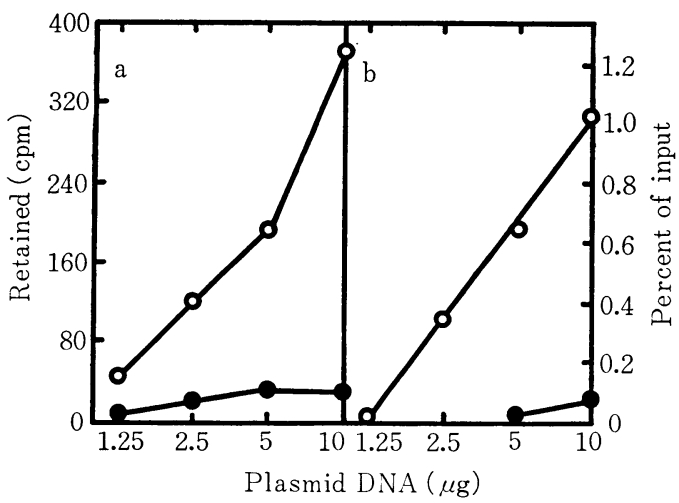

Fig. 1 Hybridization between purified $\mathrm{Ti}$ plasmid DNA and ${ }^{3} \mathrm{H}$-labeled whole cell DNA. Plasmid DNAs were purified from 1D1159 (a) and 1D135 (b) as described in 2. Materials and Methods and after denaturation of DNAs various amounts of them were fixed on a nitrocellulose filter. ${ }^{3} \mathrm{H}$-labeled whole cell DNAs were prepared from (a) 1 D1159 (-O-) and 1D1300 (-O-) and from (b) $1 \mathrm{D} 1135(-\mathrm{O}-)$ and $1 \mathrm{D} 1329(-\mathrm{O}-)$ according to the method described in 2 . Materials and Methods. ${ }^{3} \mathrm{H}$-DNAs $\left(3 \times 10^{4}\right.$ $\mathrm{cpm}$ ) were applied to each reaction mixture for hybridization.
Less than one tenth of $\left[{ }^{3} \mathrm{H}\right]$ thymidine-labeled whole DNAs from 1D1300 and 1D1329 were hybridized compared with those from virulent strains (Fig. 1). The existence of a small amount of hybridizing DNA in 1 D1300 and $1 \mathrm{D} 1329$ can be explained by the contamination of host DNA in the purified plasmid DNA fraction.

To check the second possibility, isolation of

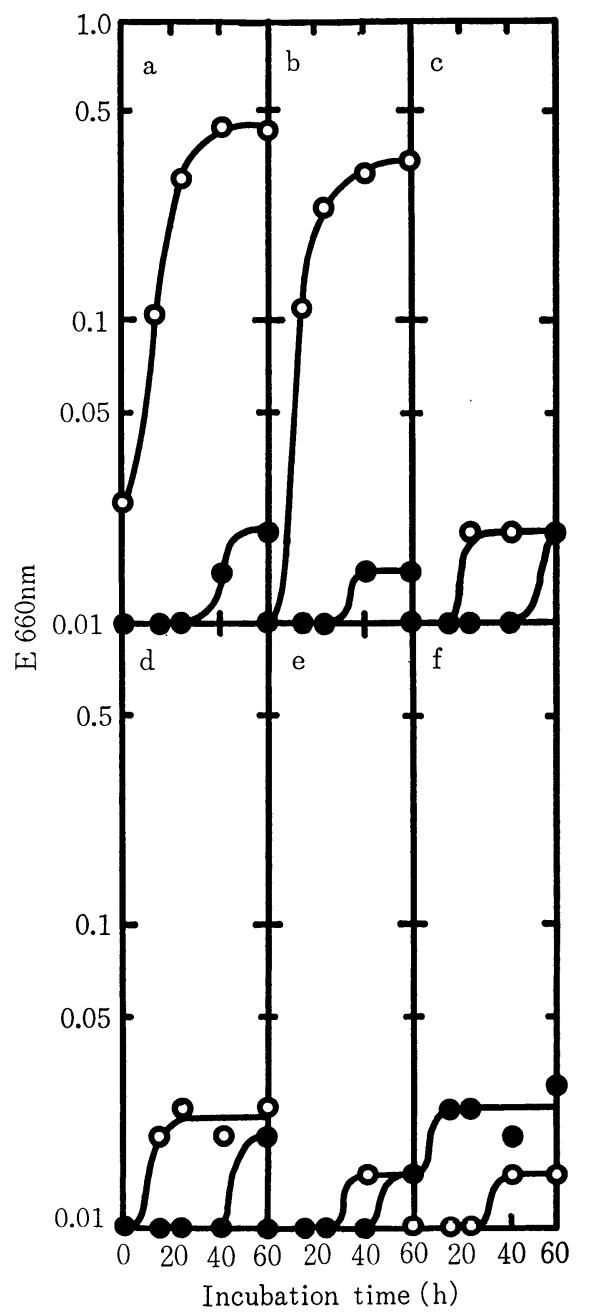

Fig. 2 Abilities to utilize nopaline and isonopaline by Agrobacterium strains harboring nopaline-type plasmid, 1D1159 (a) and 1D135 (b), the non-tumorigenic strains derived from them, 1D1300 (d) and 1D1329 (e), and by strains harboring octopine-type plasmids B6 (c) and IAM1525 (f) as their sole nitrogen source. Nopaline (-O-), iso-nopaline (-O-). 
plasmid DNAs from 1D1300 and 1D1329 were carried out by the methods described in 2 . Materials and Methods. Though the experiments were repeated, no covalently closed circular(CCC)-DNA band under ultraviolet light at $365 \mathrm{~nm}$ was detected by $\mathrm{CsCl}$-ethidium bromide centrifugation (data not shown). Thus in the strains, 1D1300 and 1D1329, no plasmid was detected and these strains contained almost no Ti-plasmid DNA sequence. There remained only little possibility that these strains contain a small segment of Ti-plasmid integrated in the host chromosome.

3.2 Gene locations controlling tumor induction and nopaline utilization

Since 1D1300 and 1D1329 were determined to contain almost no plasmid DNA sequence, identification for strict localization of the genes controlling both induction of crown gall tumor and utilization of nopaline, a sole nitrogen source, becomes possible. Strains, 1D1159, 1D135, 1D1300 and 1D1329 grown on LB agar slants were inoculated to the stems of Kalanchoë daigremontiana and sunflower. Strains, 1D1159 and 1D135 induced crown gall tumor in both plants while strains, $1 \mathrm{D} 1300$ and $1 \mathrm{D} 1329$ did not (data not shown). Thus the gene controlling the induction of crown gall tumor was further supported to locate on the plasmid DNA, in addition to the preceeding evidences ${ }^{1,7)}$.

Since strains, 1D135 and 1D1159 were reported to utilize nopaline as a sole nitrogen source $^{7)}$, the ability of the plasmid-cured strains to utilize nopaline was analyzed. B6 and IAM1525, which were known to utilize octopine as the sole nitrogen source were used as control strains. Iso-nopaline, a stereochemical isomer of nopaline, was also used to check specificity of nopaline utilization. As shown in Fig. 2, only 1D1159 and 1D135 utilized nopaline and 1D1300, 1D1329, B6 and IAM1525 had no ability to utilize it. Additionally, all these strains could not utilize iso-nopaline. From these results it was demonstrated that the gene controlling specific nopaline utilization locates on plasmid DNA.

We were grateful to Dr. K. Syōno for valuable discussions and to Miss T. Imaizumi for typing the manuscript. This research was supported by a Grant-in-Aid for Special Project Research from the Ministry of Education, Science and Culture of Japan (No. 56113009).

\section{References}

1) Zaenen, I., et al.: J. Mol. Biol., 86, 109 (1974)

2) Montoya, A.L., et al.: J. Bacteriol., 129, 101 (1977)

3) Petit, A., et al.: Nature, 271, 570 (1978)

4) Klapwijk, P. M., et al.: J. Bacteriol., 136, 775 (1978)

5) Watson, B., et al.: ibid., 123, 255 (1975)

6) Sheikholeslam, S., et al.: Amer. Soci. for Microbiology, 132 (1978)

7) Lin, B.C. and Kado, C.I.: Can. J. Microbiol., 23, 1554 (1977)

8) Van Larebeke, N., et al.: Molec. Gen. Genet., 152, 119 (1977)

9) Hatanaka, S.-I., et al.: Phytochemistry, 21, 225 (1982)

10) Currier, T.C. and Nester, E.W.: J. Bacteriol., 126, 157 (1976)

11) Guerry, P., et al.: ibid., 116, 1064 (1973)

12) Denhardt, D.T.: Biochem. Biophys. Res. Commun., 23, 641 (1966) 